S3 Table. Research topics in molecular biology.

\begin{tabular}{|c|c|c|}
\hline Topic & Representative words & Representative journals \\
\hline B0 & cell express activ signal develop & $\begin{array}{l}\text { Development, Molecular and Cellular Biology, Can- } \\
\text { cer Research, Genes \& Development, Journal of } \\
\text { Immunology }\end{array}$ \\
\hline B1 & patient increas studi p signific & $\begin{array}{l}\text { Journal of Clinical Investigation, Cancer Research, } \\
\text { Circulation, Diabetes, Investigative Ophthalmol- } \\
\text { ogy \& Visual Science }\end{array}$ \\
\hline B2 & protein structur bind dna site & $\begin{array}{l}\text { Biochemistry, Nucleic Acids Research, Molecular } \\
\text { Cell, Journal of The American Chemical Society, } \\
\text { EMBO Journal }\end{array}$ \\
\hline B3 & use model method data protein & $\begin{array}{l}\text { Biophysical Journal, Nucleic Acids Research, Jour- } \\
\text { nal of The American Chemical Society, Physical } \\
\text { Review Letters, Physical Review B }\end{array}$ \\
\hline B4 & channel receptor neuron cell activ & $\begin{array}{l}\text { Journal of Neuroscience, Neuron, Journal of Neu- } \\
\text { rophysiology, Nature Neuroscience, Journal of } \\
\text { Physiology-London }\end{array}$ \\
\hline B5 & $\begin{array}{l}\text { gene mutat sequenc genom chro- } \\
\text { mosom }\end{array}$ & $\begin{array}{l}\text { Nature Genetics, Genetics, Nucleic Acids Research, } \\
\text { Genome Research, American Journal of Human } \\
\text { Genetics }\end{array}$ \\
\hline B6 & virus infect cell viral protein & $\begin{array}{l}\text { Journal of Virology, Virology, Journal of Immunol- } \\
\text { ogy, Journal of Experimental Medicine, Nature } \\
\text { Medicine }\end{array}$ \\
\hline B7 & $\begin{array}{l}\text { protein membran cell transport } \\
\text { vesicl }\end{array}$ & $\begin{array}{l}\text { Journal of Cell Biology, Molecular Biology of The } \\
\text { Cell, EMBO Journal, Journal of Cell Science, } \\
\text { American Journal of Physiology }\end{array}$ \\
\hline B8 & male femal behavior sex receptor & $\begin{array}{l}\text { Endocrinology, Development, Hormones and Be- } \\
\text { havior, Developmental Biology, Journal of Com- } \\
\text { parative Neurology }\end{array}$ \\
\hline B9 & $\begin{array}{l}\text { cell microtubul protein spindl mi- } \\
\text { tot }\end{array}$ & $\begin{array}{l}\text { Journal of Cell Biology, Molecular Biology of } \\
\text { The Cell, Current Biology, Genes \& Development, } \\
\text { Molecular and Cellular Biology }\end{array}$ \\
\hline B10 & $\begin{array}{l}\text { speci sequenc phylogenet group } \\
\text { data }\end{array}$ & $\begin{array}{l}\text { Molecular Biology and Evolution, Genetics, Amer- } \\
\text { ican Journal of Botany, Systematic Botany, Molec- } \\
\text { ular Phylogenetics and Evolution }\end{array}$ \\
\hline B11 & actin cell protein filament myosin & $\begin{array}{l}\text { Journal of Cell Biology, Journal of Cell Science, } \\
\text { Molecular Biology of The Cell, Current Biology, } \\
\text { Neuron }\end{array}$ \\
\hline B12 & gene methyl histon cell dna & $\begin{array}{l}\text { Molecular and Cellular Biology, Genes \& Develop- } \\
\text { ment, Molecular Cell, Genetics, Nature Genetics }\end{array}$ \\
\hline B13 & $\begin{array}{l}\text { protein degrad ubiquitin substrat } \\
\text { cell }\end{array}$ & $\begin{array}{l}\text { Molecular Cell, Molecular and Cellular Biology, } \\
\text { EMBO Journal, Genes \& Development, Journal of } \\
\text { Virology }\end{array}$ \\
\hline
\end{tabular}

Continued on next page 
S3 Table. Continued from previous page

Topic Representative words

B14 plant express gene protein cell

B15 gene $\mathrm{v}$ iron bacteria express

B16 c elsevi right reserv all

B17 oxid no activ nitric heme

B18 beta radic 2 dot center

B19 light protein gene express arabidopsi

B20 proteas inhibitor parasit activ cystein

B21 telomer telomeras rna dna cell

B22 class cell peptid t molecul

B23 receptor activ thrombin bind platelet

B24 charg lipid cation nmr concentr

B25 cell oxidas neutrophil activ mice

B26 tumor dna skin mice adduct
Representative journals

Plant Cell, Plant Journal, Plant Physiology, Plant Molecular Biology, Molecular Plant-Microbe Interactions

Journal of Bacteriology, Molecular Microbiology, Infection and Immunity, Applied and Environmental Microbiology, Biotechnology and Bioengineering

Developmental Biology, Bioorganic \& Medicinal Chemistry Letters, Tetrahedron Letters, FEBS Letters, Biochemical and Biophysical Research Communications

Biochemistry, Investigative Ophthalmology \& Visual Science, Biochemical and Biophysical Research Communications, Archives of Biochemistry and Biophysics, Free Radical Biology and Medicine Biochemistry, Journal of the American Chemical Society, Physical Review B, Physical Review Letters, Inorganic Chemistry

Plant Cell, Plant Physiology, Plant Journal, Genetics, Planta

Biochemistry, Journal of Medicinal Chemistry, Chemistry \& Biology, Molecular and Biochemical Parasitology, Bioorganic \& Medicinal Chemistry Letters

Molecular and Cellular Biology, Genes \& Development, Nucleic Acids Research, Molecular Cell, RNA-A Publication of the RNA Society Journal of Immunology, Journal of Experimental Medicine, European Journal of Immunology, Immunity, International Immunology

Blood, Journal of Clinical Investigation, Biochemical Journal, Journal of Pharmacology and Experimental Therapeutics, Molecular Endocrinology

Biochemistry, Journal of The American Chemical Society, Biophysical Journal, Langmuir, Journal of General Physiology

Blood, Journal of Immunology, Journal of Experimental Medicine, Journal of Leukocyte Biology, Calcified Tissue International

Cancer Research, Molecular Carcinogenesis, Biochemistry, Carcinogenesis, Chemical Research In Toxicology

Continued on next page 
S3 Table. Continued from previous page

\begin{tabular}{cl} 
Topic & Representative words \\
\hline B27 & phage gene genom rate cell \\
B28 & $\begin{array}{l}\text { shock heart heat ventricular car- } \\
\text { diac }\end{array}$
\end{tabular}

B29 anion complex 1 angstrom 2

B30 mice cholesterol receptor apo cell

B31 zone fluid soil site depth

B32 coli e assembl pilus bladder

B33 ant coloni popul speci albican

B34 surfac cell antibodi use film

B35 cell protein signal kinas chemotaxi

B36 spd lung macrophag cell protein

B37 protein aggreg diseas beta prion

B38 ligand bind structur kringl acid

B39 resist cell drug efflux mutant

\section{Representative journals}

Journal of Bacteriology, Evolution, Molecular Biology and Evolution, Virology, RNA-A Publication of The RNA Society

American Journal of Physiology-Heart and Circulatory Physiology, Circulation Research, Circulation, Journal of Cardiovascular Electrophysiology, Heart Rhythm

Journal of The American Chemical Society, Biochemistry, Chemical Communications, Journal of Organic Chemistry, Inorganic Chemistry Journal of Lipid Research, Journal of Clinical Investigation, Circulation Research, Arteriosclerosis Thrombosis and Vascular Biology, Lipids

Development, Journal of Neuroscience, American Journal of Pathology, Geology, Journal of Geophysical Research-Planets

Infection and Immunity, Journal of Bacteriology, Molecular Microbiology, EMBO Journal, Organic \& Biomolecular Chemistry

Genetics, PLOS Biology, Evolution, Molecular Ecology, Insectes Sociaux

Physical Review B, Applied Physics Letters, Langmuir, Journal of Physical Chemistry B, Nature Biotechnology

Journal of Bacteriology, Molecular Microbiology, Biophysical Journal, Planta, Microbial Ecology

Journal of Immunology, American Journal of Respiratory Cell and Molecular Biology, Journal of Clinical Investigation, American Journal of PhysiologyLung Cellular and Molecular Physiology, Infection and Immunity

Protein Science, Human Molecular Genetics, Annals of Neurology, ACS Chemical Biology, Archives of Neurology

Biochemistry, Journal of The American Chemical Society, Journal of Biomolecular NMR, Protein Engineering, Proteins-Structure Function and Genetics

Journal of Bacteriology, Antimicrobial Agents and Chemotherapy, Molecular Microbiology, American Journal of Physiology, Organic \& Biomolecular Chemistry

Continued on next page 
S3 Table. Continued from previous page

Topic Representative words

B40 gene cell gut $\mathrm{c}$ human

B41 matrix fiber cell type tissu

B42 l cell monocytogen host intracellular

B43 domain bind type vwf platelet

B44 mrna rna express intestin protein

B45 dna recombin protein meiotic chromosom

B46 express gene cell develop hoxa10

B47 receptor bind cell protein ligand

B48 activ insulin acid islet increas

B49 subunit alpha protein gamma beta

B50 beta alpha termin subunit lh

B51 reaction synthesi acid group use

B52 mice diseas cell bone normal

B53

\section{Representative journals}

Molecular Microbiology, Eukaryotic Cell, American

Journal of Physiology, Journal of Nutrition, Cell

Host \& Microbe

Journal of Cell Biology, Journal of Clinical Investigation, Journal of Cell Science, Journal of The Acoustical Society of America, American Journal of Respiratory Cell and Molecular Biology

Journal of Bacteriology, Infection and Immunity, Molecular Microbiology, Journal of Immunology, Journal of Experimental Medicine

Blood, Journal of Clinical Investigation, Thrombosis and Haemostasis, Journal of Thrombosis and Haemostasis, Human Gene Therapy

RNA-A Publication of The RNA Society, Journal of Lipid Research, Endocrinology, American Journal of Physiology, Biochemical and Biophysical Research Communications

Genes \& Development, Molecular and Cellular Biology, Genetics, Development, Molecular Cell

Cancer Research, Development, Developmental Biology, Molecular Endocrinology, Endocrinology

Bioconjugate Chemistry, Biochemical Journal, Journal of Neurochemistry, Journal of Medicinal Chemistry, Experimental Cell Research

Biochemistry, Diabetes, Circulation Research, Journal of Clinical Investigation, Biochemical Journal

Analytical Biochemistry, Archives of Biochemistry and Biophysics, Applied Microbiology and Biotechnology, Molecular Plant-Microbe Interactions, Journal of Phycology

Molecular Endocrinology, Endocrinology, Molecular and Cellular Endocrinology, Clinical Orthopaedics and Related Research, Bio-Technology Journal of The American Chemical Society, Biochemistry, Organic Letters, Tetrahedron Letters, Journal of Organic Chemistry

Journal of Clinical Investigation, Blood, Investigative Ophthalmology \& Visual Science, Molecular Therapy, Journal of Bone and Mineral Research Molecular and Cellular Biology, Biochemical and Biophysical Research Communications, Biochemical Journal, Biotechniques, American Journal of Physiology-Endocrinology and Metabolism 
S3 Table. Continued from previous page

\begin{tabular}{cl} 
Topic & Representative words \\
\hline B54 & $\begin{array}{l}\text { transcript activ promot bind pro- } \\
\text { tein }\end{array}$ \\
B55 & cell protein assembl flagellar cilia \\
B56 & cell oscil neuron period cycl \\
B57 & reductas degrad protein cell $\mathrm{j}$
\end{tabular}

B58 mitochondri cell protein death mitochondria

B59 replic cell gene dna protein

B60 toxin alpha nakatpas express cell

B61 gene express protein cell 1433

B62 neuron express gene olfactori drosophila

B63 m tuberculosi infect immun secret

B64 protein coli respons gene stress

B65 gene element boundari express domain

B66 protein activ kinas signal inhibit

B67 activ kinas enzym acid phosphoryl

B68

\section{Representative journals}

Molecular and Cellular Biology, Genes \& Development, Molecular Cell, EMBO Journal, Journal of Virology

Journal of Cell Biology, Development, Cell Motility and The Cytoskeleton, Current Biology, Genetics Journal of Neuroscience, Neuron, Journal of Neurophysiology, Nature Neuroscience, PLOS One Archives of Biochemistry and Biophysics, Circulation, American Journal of Medical Genetics, Calcified Tissue International, Protein Expression and Purification

Molecular and Cellular Biology, Journal of Clinical Investigation, Circulation Research, Archives of Biochemistry and Biophysics, Current Genetics Journal of Bacteriology, Molecular Microbiology, Genes \& Development, Molecular Cell, Genetics Developmental Biology, FEBS Letters, Memorias Do Instituto Oswaldo Cruz, Insect Biochemistry and Molecular Biology, European Journal of Biochemistry

Plant Physiology, Plant Molecular Biology, Plant Cell, Plant Journal, Maydica

Development, Neuron, Journal of Neuroscience, Genes \& Development, Developmental Biology

Infection and Immunity, Molecular Microbiology, Journal of Experimental Medicine, PLOS Pathogens, Structure

Journal of Bacteriology, Genes \& Development, Molecular Microbiology, Molecular Cell, Molecular Biology of The Cell

Development, Genes \& Development, Molecular and Cellular Biology, Genetics, Nucleic Acids Research

Chemistry \& Biology, Cell Calcium, Science Signaling, Journal of Experimental Biology, Mutation Research

Biochemistry, Journal of Bacteriology, Biotechnology and Bioengineering, Applied Microbiology and Biotechnology, Archives of Biochemistry and Biophysics

respons call pattern select differ Journal of Neuroscience, Journal of Neurophysiology, Journal of The Acoustical Society of America, Journal of Molecular Evolution, Hearing Research 
